\title{
Small medium micro enterprise business goals and government support: A South African case study
}

\author{
R. Peters \\ University of the Western Cape, Modderdam Road, Bellville, Cape Town, \\ Republic of South Africa, 7535 \\ V. Naicker* \\ *University of South Africa, Cnr Janadel \& Alexandra Avenues, Midrand, JHB \\ Republic of South Africa, 7535 \\ naickv@unisa.ac.za
}

\begin{abstract}
Small and medium-scale enterprises (SMMEs) form the majority of the enterprises in the South African economy. The South African government has identified the SMME sector as one of the potential enablers to achieve its objectives of improving job creation opportunities, reducing poverty and creating a more equitable distribution of wealth. The aim of this article was to provide a perspective on the success government support initiatives has had on the SMME sector. To achieve this, the study sought to analyse the perceived strengths and weaknesses of government's national strategy and its institutions tasked with creating an enabling environment for the sector. The study employed a survey research design methodology in which mixed methods were used. The national business strategy employed by government was critically analysed. Empirical data was collected from 282 respondents in order to answer the research question. The results show that the government's approach has favoured 'supply-side interventions' including, providing access to training, credit, mentoring and information to existing and new business. Furthermore, this study has identified the lack of awareness as the primary reason for the under-delivery of the government support initiatives in SMME development. Respondents indicated that they frequently made use of the services of business consultants and external specialists from which they perceived added more value to their respective businesses.
\end{abstract}

*To whom all correspondence should be addressed.

\section{Introduction}

The government has identified the small, medium and micro enterprise sector (SMME) as one of the potential means of creating an enabling environment by improving job creation opportunities and wealth distributions necessities (Department Trade and Industry 1995). If the government's strategy to use the SMME sector is to have any significant success, focus must be placed on developing competent entrepreneurs, especially amongst those classified as previously disadvantaged persons.

According to Guzmán \& Santos (2001) the entrepreneurial quality of the SMME owner is a critical factor affecting SMMEs' ability to overcome barriers to survival and achieve sustainable growth. The national strategy for small business development, referred to as the National Small Business Strategy (NSBS), was formally endorsed by the South African Parliament in 1995. This strategy established several important objectives for the SMME sector when dealing with problems it was facing.

The most common problems included an unfavourable legal environment, lack of access to markets and procurement, lack of access to finance and credit, low skills levels, lack of access to information and, lastly, a shortage of effective supportive institutions (Republic of South Africa 1996).

Considering the current supply side measures and its effectiveness to date, smaller towns and rural areas enjoy even less support from government institutions in terms of fostering an enabling environment conducive to creating and or expanding SMME's, as opposed to urban areas (Peters 2009). A consequence of apartheid was the location of previously disadvantaged communities that were purposefully situated outside and far removed from towns, city centres and more importantly developed hubs. This indicates a need for planning from a spatial perspective.

Many services under the auspices of Local Economic Development (LED) are available through local government structures, such as municipalities. Although they are most aware of problems faced by entrepreneurs in their respective districts, unfortunately most of these municipalities do not have the capacity to render efficient or effective support to existing and would-be entrepreneurs.

LED has gained considerable prominence in development planning. The government's neo-liberal macro-economic agenda sought a market-driven economic expansion and 
growth strategy, facilitating market expansion, with local government playing a key role in stimulating economic development through investment in infrastructure to "crowd in private investment and boost short-term economic performance" (RSA 1996).

According to Peters (2009), considerable emphasis was placed on 'developmental local government', increasing the role of government, particularly local agencies, in promoting growth and development, thus entrenching an essentially pro-poor policy focus. The government saw the central responsibility of municipalities as being to work together with local communities to find sustainable ways to meet their needs and improve the quality of their lives (Department of Provincial Affairs 1998).

Keeping in mind the urban versus rural bias, the focus of this research will be on SMMEs operating in towns, small towns and rural areas in and around the Kwa-Zulu Natal province in South Africa. This province is home to the large portion of the South African population and is one of the poorest in the country in terms of the poverty gap.

\section{Rational of this research}

SMMEs are potentially of great socio-economic significance in employment creation, closing the income inequality gap and alleviating poverty. In response to the challenges set out by government and documented in a DTI (1995) the Center for Small Business Promotion (CSBP) of the Department of Trade and Industry (DTI) and the National Small Business Council (NSBC), as well as other developmental agencies, were established to drive the National Small Business Strategy.

It was expected from these DTI programmes and other programmes administered by its apex institutions, Khula (credit) and Ntsika (now Small Enterprise Development Agency (SEDA) - training) to build the technical and financial capacity of Small-, Medium- and Micro-sized enterprises.

The purpose on the part of the SA government was to foster a culture of entrepreneurship particularly amongst African Blacks, the success of which could be measured by improved competitiveness in terms of turnover growth and employment creation. Throughout the 1990s and to date, most of the research conducted into the effectiveness of government support has focused on the major economic regions in South Africa, whilst neglecting the rural and small town SMMEs (Rogerson 2000).

This study aims to contribute to closing the gap on an urban bias against the rural and small town SMMEs, where a more targeted government support programme is urgently needed.

\section{Literature review}

SMMEs are potentially of great socio-economic significance in employment creation, closing the inequality gap and alleviating poverty. In response to the challenges set out by government and documented in a DTI (1995) the Center for Small Business Promotion (CSBP) of the Department of Trade and Industry (DTI) and the National Small Business Council (NSBC), as well as other developmental agencies, were established to drive the National Small Business Strategy.

It was expected from these DTI programmes and other programmes administered by its apex institutions, Khula (credit) and Ntsika (now Small Enterprise Development Agency (SEDA) - training) to build the technical and financial capacity of Small-, Medium- and Micro-sized enterprises (Peters 2009). Also, a number of specific programmes had been introduced by the Industrial Developed Corporation (IDC) and the DTI.

In many developed countries, the late 1970s and 1980s witnessed the re-emergence of SMME's, due to two major events. Firstly, spectacular cases of large enterprises running into economic difficulties and shedding employment arose in nearly all industrialized countries, while the SMME sectors, or parts of them, fared relatively well through a period of economic turbulence that had started in the early 1970s. Second, Birch $(1979 ; 1987)$ found that SMMEs created the majority of new jobs in the USA. This provoked an upsurge in research into employment shifts towards smaller units.

The OECD concluded in 1985 that, in several of its member states, a tendency towards the concentration of workers in small firms could be found, even after accounting for shifts in developed structure or sectoral composition (OECD, 1985). After having reviewed data on employment shares by enterprise size for nine industrialised countries, (Sengenberger, Loveman \& Piore., 1990:8) confirm that: despite significant cross-national differences in the size distribution and despite methodological caveats, the employment share of small enterprises has reversed a downward trend that had prevailed for many decades and risen significantly.

Keeping this in mind, it is important to guard against rushing into premature and overly general conclusions on the economic and social implications of the shift toward smaller units (Harrison, 1994). Job generation studies show that the employment dynamics accompanying new firm formations and business closures is very important to net employment contribution of small units (Becattini, 1990; Koshiro, 1990; Mead, 1999).

Many of the recent births of small firms in developed countries may have been induced by poor economic conditions in general, and by high unemployment in particular. Those undertaken as 'last-ditch' attempts to provide livelihoods to the founder may rest on rather shaky grounds, and their failure rate might, therefore, be expected to be abnormally high, as either 'good times' draw the entrepreneur back into dependent employment or 'bad times' topple the weak firm (Sengenberger et al., 1990). 
Still, it has now been acknowledged that a large majority of business units in developed countries are small, and even a conservative review of the job generation literature suggests that small firms account for at least a proportional share of employment creation. Net new jobs created in small firms, however, result from a very dynamic process of expansion and contraction within the small firm sector.

While some small firms start and remain small throughout their existence, others experience stages of growth, and senescent firms even decline (Timmons 1994).Large employment gains occur seemingly only in a few small firms (Sengenberger et al., 1990; Qualman, 1988; Mead 1999).Indeed, recent research by the European Commission has shown that only enterprises characterised as fastgrowing SMEs contributed some $50 \%$ of net job creation (Papoutsis 1996).

Historically in African as well as in other less developed countries, SMMEs (and micro enterprises in particular, which constitute the majority) have received mounting attention because of their labour-absorptive capacity in times of a shrinking of both public sector and private formal economy, and increasing numbers of new labour entrants. With the shift of industrial policy away from importsubstitution and of trade policy towards liberalisation, SMMEs are moreover expected to respond flexibly and thus withstand global competition (Hirst \& Zeitlin, 1992; Bambara, 1995; Kaplinsky, 2010).

While the Latin American experience of both single and especially clustered SMEs confirm the dynamism associated with SMMEs (Cortes, Berry \& Ishaq, 1987) there has been little systematic evidence of the incidence of microenterprise 'graduation' or growth into larger ones in Africa (Mead 1999).Indeed, one-person operations constitute the majority of small-scale industry in Africa, and only about $1 \%$ succeed in graduating to an intermediate-size (Dia, 1996; McPherson, 1996).

Product specialisation is, in most cases, not a strategic answer to segmented markets, but to lack of resources (Pedersen \& McCormick, 1996; Amsden, 1997). Virtually all SMMEs operate in conditions of excess supply of relatively unskilled and unorganised labour, which allows them to transmit the burden of unstable markets to their employees and to base competition on squeezing labour costs rather than innovation or technological upgrading (McCormick, 1999).

Unlike in South Korea, where large firms function as catalysts for growth to their subcontractors, corporate subcontracting to small and mostly 'informal' firms in Africa is more than often a means to reduce costs by exploiting labour-surplus conditions and circumventing regulations and trade union organisations (Pedersen \& McCormick, 1996).Clusters of sector-specific firms do exist in Africa, but their growth experiences vary and differ markedly from other developing country cases, such as the successful Sinos Valley shoe cluster in Brazil; the surgical instruments cluster in Sialkot, Pakistan; or from the 'model' industrial districts of Italy (Yankson, 1996; Advani, 1997; McCormick, Kinyanjui \& Ongile, 1997; McCormick 1999).

Indeed, strong social ties and networking, reported to be essential for the success of industrial districts in Europe, have ambiguous effects on firm growth in Africa. While being supportive amongst the Igbo in Nigeria, research in Kenya suggests that the successful African entrepreneur has loosened his or her networks, based on kinship and social ties in general (Brautigam, 1997; Ferrand, 1997).

Furthermore, formal institutions in Africa face crises of legitimacy and enforcement by not being rooted in local culture and are, therefore, far from conducive to enterprise growth (Dia 1996). The above suggests that modes of competition and growth trajectories of SMMEs vary across continents and countries (Khoza 1994; Humphrey \& Schmitz 1995; Amsden 1997). Research findings on SMMEs throughout Africa are diverse, although they show widely that it cannot be enterprise size as such which determines a firm's growth potential for success and failure of SMMEs co-exist and instead point to the role of the entrepreneur (Sengenberger et al., 1990; Späth 1994).

The predominance of SMMEs in the industrial sector, both in terms of numbers and employment opportunities generated, does demonstrate that SMMEs form an important part of African economies. Nevertheless, the critical underlying issues of the viability of these small firms, and the sustainability and quality of the employment generated by them remain unclear (Späth, 1994; Dia, 1996; McCormick et al., 1997).

Since the elections of April 1994, the issues of BEE and a more equal income distribution have been placed high on the agenda of the new government of South Africa (Rogerson \& Rogerson, 1995). Nevertheless, the need to take the South African economy onto 'a higher road', with a diversified economy in which productivity and international competitiveness is enhanced, investment is stimulated and entrepreneurship flourishes, is recognised as a condition to address these issues successfully (RSA, 1996; DPA, 1995). SMMEs are seen as vehicles to:

Address the problem of high unemployment levels in South Africa, because of their high labour-absorptive capacity;

- Activate domestic competition by creating market niches in which they grow until they identify a new niche as a response to demand changes, and for them to be internationally competitive because of their flexibility;

- Redress the inequalities inherited from the apartheid period - in terms of patterns of economic ownership and restricted career opportunities for Black employees;

- $\quad$ Contribute to Black Economic Empowerment (BEE), in that the majority of SMMEs are reported to be 
initiated, owned or controlled by those members of society who were discriminated against in South Africa's past; and,

- Play a crucial role in peoples' efforts to meet basic needs in the absence of social support systems during restructuring processes - which refers in particular to South Africa's micro-enterprise segment, especially survivalist activities characterised by low entry barriers for inexperienced job seekers

Pretorius \& Vuuren (2003) argue that economic incentives do not favour SMMEs, and believe the core focuses of government programmes, as promulgated through DTI and its apex organisations include finance, growth, expansion and competitiveness assistance programmes, are more relevant to existing businesses than to start-ups. In a survey conducted by the Global Entrepreneurship Monitor (GEM) in 2004, less than one-in-ten respondents rated as effective the government's overall effort to promote the SMME sector.

The findings of the Reynolds et al. (2003) survey suggested that this dilemma in the main was caused because of poor communication on the part of government support agencies. Peters (2009)states that the intention on the part of government was to foster a culture of entrepreneurship amongst African Blacks in particular the success of which can be measured by improved competitiveness in terms of turnover growth and employment creation. Throughout the 1990s and to date, most of the research conducted into the effectiveness of government support has focused on the major economic regions such as Gauteng or Western Cape in South Africa, whilst neglecting the rural and small town SMMEs (Rogerson, 2000)

The government, through the Department of Trade and Industry (DTI), established the Center for Small Business Promotion (CSBP) at National level. This centre in turnestablished Ntsika Enterprise Promotion Agency (now the Small Enterprise Development Agency - SEDA) and Khula Enterprise Finance Limited. These are the main statutory bodies established to support and assist SMMEs (Naicker, 2006).

The DTI (1995)stipulates that the SA government's role is one of facilitator as opposed to an implementer. According to Peters (2009) the implementation of the NSBS relies on a partnership of national, provincial and local governments), NGOs, parastatals, community-based organisations, business associations, the private sector and foreign donor agencies. The DTI initially envisaged the partnership as between Khula, which facilitates access to finance, and Ntsika, which facilitates access to non-financial areas of SMME support. SMMEs themselves were to participate in the partnership through a Small Business Council (now defunct), with provincial government support to be channelled through SMME Desks, created in each of the nine provinces.

A number of SMME development initiatives were started after the installation of the democratically elected South
African government in April 1994. The government saw underdeveloped and undeveloped SMMEs as a window of opportunity to address the challenges of job creation, economic growth and equity in South Africa. The starting point for the process of small business development was to create an enabling environment. The discussion document on the strategy and policy for SMMEs was released at the end of October 1994, resulting in the White Paper on a National Strategy for the Development and Promotion of Small Business in South Africa that was passed by the government in March 1995.

Linked to the provision of services by government to the emerging SMME sector is the issue of compliance by small enterprises with generally accepted standards of business behaviour. Most of the SMME enterprises in South Africa are not registered. Common reasons for non-registration include the lack of desire or capacity to keep detailed records and the erroneous belief that non-registration evades VAT. In fact, input Value Added Tax (VAT) remains payable even if the output VAT is not remitted. Thus, the burden of paperwork for often non-literate SMME operators, the survivalist nature of many SMME activities and the short term nature of many such enterprises can be cited as some of the reasons that mitigate against business registration.

It is against this background of stagnant job creation and the new government facing the political reality of the need for rapid job creation that SMMEs were seen as one significant part of the broader economic growth strategy. The broad strategy of economic growth is outlined in the GEAR (Growth, Employment and Redistribution) document, and includes engagement in global competition and the reduction of protective trade barriers, curbing labour wage demands, identifying potential economic clusters, reduction in state subsidies for industry, and macroeconomic balance ( Colbert, 1999).

Support of SMMEs in the survivalist, micro and small business sector usually targets the need for basic business skills training for emergent entrepreneurs and the need for better access to capital. In South Africa, these two issues in particular have formed the cornerstone in the government's strategy for SMME promotion and development (Colbert, 1999).This is based on the premise that past market failures, including restrictions on Black business ownership and access to finance must be addressed in order to create an enabling environment for SMME development (Ebersohn, 1997). The motivation for South African government support of the SMME sector is an increase in political stability that has coincided with greater access by small business employment, even if on a survivalist scale.

Tendler and Amorim (1996) indicate that most assistance to SMMEs world-wide is supply driven, that is, assistance takes the form of providing one or more on-going services to emergent business, often including access to credit, business management training or technical assistance. Supply-side assistance is generic in nature and is applied 
across sectors in an attempt to service a maximum number of client enterprises (Tendler \& Amorim, 1996).

Among other noted deficiencies of this supply-sided approach to the provision of business skills is that business training is not grounded in the harsh environment of the marketplace where business training must eventually be put in practice (Kuroda \& Kasajima, 1987).Thus, the particular problems and market distortions that gave rise to the need for SMME training initiative in the first place are not being addressed in the context of the marketplace, but rather as a training component that, once learned, is implicitly assumed transferrable to the marketplace (Tendler \& Amorim, 1996).

There is substantial contrary evidence to indicate that business learning is quickest, most efficient and relevant when it is directly related to the marketplace (Kuroda \& Kasajima, 1987). In general, the elements of the SMME support framework envisioned by the DTI (1995) relate most directly to the capacity of the government to effectively interact with the SMME sector. The provision of specific services to SMMEs thus comes off as secondary to developing the capacity of government to understand and have an impact upon the activities of the SMME sector.

For example, out of 21 suggestions for the SA government action to create more effective support of SMMEs (DTI, 1995) 13 were related primarily to the inner workings of government, three to improved access to finance, two to training needs of SMMEs, one to information collection and dissemination, and one to the promotion of joint ventures between larger and smaller enterprises (DTI, 1995).

Three issues have emerged as paramount, namely the development of support for SMME in South Africa. This has been an area that has been grossly neglected by previous governments, especially for persons of colour. The present government views the passage of new legislation to define its own role as a fundamental task for support of SMMEs. Second, SMME support will focus on the formation of new quasi-governmental institutions to improve access to finance, commonly believed, but not always proven, to be the major obstacle facing emergent entrepreneurs (Meyanathan, 1994). Generic business skills, financial management and general entrepreneurial skills are the third focus of the DTI's national strategy for SMME support (DTI, 1995).

\section{Methodology}

The findings of prior studies discussed above suggest that the government should strive to foster an entrepreneurial culture amongst previously disadvantaged groups in South Africa. The success of such initiatives can be measured by improved competitiveness in terms of (1) employment creation and (2) turnover growth. Competitiveness derives from the creation of the locally differentiated capabilities to sustain growth in an internationally competitive environment (Fan, 2009). The improvement in employee numbers should be measured by increases in permanent employment. Turnover, on the other hand, is defined as a measure of sales that is generated for each rand invested in operating assets.

The Small Enterprise Development Agency (SEDA) has scant databases for SMMEs registered in the respective districts. The researcher then set out to make contact with SMME's listed on the SEDA database to set up interviews and complete the research instrument. What became evident was that the significance of using these databases is that most registered businesses were in existence for more than one year and were not classified as survivalist. Also, all businesses listed on the database were involved in manufacturing (or some derivative thereof), retailing, agribusiness and transport which are the biggest contributors to the gross geographic product (GGP) for the province. Further to this, these criteria ensure that the inclusion of owners/managers with a reasonable understanding of minimum wages, turnover, government initiatives and the concept of BEE.

In order to evaluate the impact of the government support initiatives to assist the SMME sector in employment creation and turnover growth in the Kwazulu-Natal province in South Africa, an empirical survey, by means of a structured questionnaire, was conducted in the province. The population of the study consists of owner/managers of small and medium sized enterprises (as classified in Government White Paper 2001) delineated to manufacturing firms, transport, agribusiness and retail business in the KwazuluNatal province.

The study was conducted in two phases, using a survey design with the pilot study which was conducted in 30 organisations to test the feasibility of the research instruments. The reliability $(0,845)$ of the final instrument was calculated using Cronbach Alpha. The pre-study experience was then used to refine the questionnaire, conceptual framework and methodology for the main fieldwork. In total, 282 businesses were interviewed across districts of the KwaZulu-Natal province.

The pilot study was also used to identify potential practical problems in following the research procedure. For example, problems such as poor recording and response rates were to be identified and precautionary procedures or 'safety nets' were devised. Thus, a small group of respondents who were as similar as possible to the target population was used. The questionnaire was then administered to the pilot respondents, in the same way as it was administered in the main study.

The areas covered by the final questionnaire on the demographics and opinion of SMME owners/managers on the effectiveness of government SMME support initiatives are summarised below:

the age, gender and level of qualification of the respondents;

the period during which the business is incepted;the form of business owned by the entrepreneur; 
- $\quad$ the awareness of the government support agencies;

- $\quad$ the usage of government support agencies;

- opinions of the SMME owners/managers on the government support services;

- the effectiveness of the government initiatives rated by the SMME owners/managers; and

- the obstacles of the SMMEs to achieving business goals.

The aim of this study was to establish whether the South African government plays a significant role in supporting SMME's in Kwa-Zulu Natal province in South Africa.

The Pearson's Chi-square $\left(\chi^{2}\right)$ test is used to evaluate whether there exists a relationship between government support initiatives and the growth in the KwaZulu-Natal SMME sector. Using job creation and revenue increases as measures of growth in the SMME sector, the evaluation is divided into the following hypotheses:

H1a: There is no relationship between government support initiatives and SMME growth in terms of employment creation in the past two years;

H1b: There is a relationship between government support initiatives and SMME growth in terms of employment creation in the past two years;

H2a: There is no relationship between government support initiatives and SMME growth in terms of year-on-year revenue increases since business inception; and

H2b: There is a relationship between government support initiatives and SMME growth in terms of year-onyear revenue increases since business inception.

The items in the questionnaire were assigned Likert scale scores. The data was then processed and analysed using SPSS version 17 for Windows.

\section{Findings}

\section{Analysis of survey respondents}

Table 1 and Table 2 present the age and gender distributions of the respondents in the survey respectively. From Table 1, the majority of respondents (158) were between the ages of $31-40$ years and $18,8 \%$ (53) of the respondents were between the ages of 41-50.

Of those interviewed 98,6\% (277) were South African citizens. Table 2 indicated that $61 \%$ (172) of the respondents were male and 39\% (110) were female.
Table 1: Age of the respondents

\begin{tabular}{l|c|c}
\hline Age Group & Frequency & Per cent \\
\hline Under 21 & 1 & $0,4 \%$ \\
\hline $21-30$ & 70 & $24,8 \%$ \\
\hline $31-40$ & 158 & $56,0 \%$ \\
\hline $41-50$ & 53 & $18,8 \%$ \\
\hline Total & 282 & $100,0 \%$ \\
\hline
\end{tabular}

Table 2: Gender of the respondents

\begin{tabular}{l|c|c}
\hline Gender & Frequency & Per cent \\
\hline Male & 172 & $61,0 \%$ \\
\hline Female & 110 & $39,0 \%$ \\
\hline Total & 282 & $100,0 \%$ \\
\hline
\end{tabular}

To establish the relationship between the SMME owner/managers and the success of the business all respondents were asked to indicate their educational background. Six categories of highest qualifications were used to describe the educational characteristics. These were primary, junior secondary, senior secondary, diploma, graduate and post-graduate qualifications respectively.

Table 3 presents the distribution of the educational levels of the respondents. Approximately 36,5\% (103) of the respondents had completed a senior certificate while $10,3 \%$ (29) of respondents were graduates. Only, 3,2\% (9) of those interviewed had completed post-graduate qualification(s); $23,8 \%$ (67) completed junior secondary school and 6,4\% (18) had completed primary schooling.

\section{Table 3: Level of qualification of the respondents}

\begin{tabular}{l|c|c}
\hline Qualification & Frequency & Percent \\
\hline Primary & 18 & $6,4 \%$ \\
\hline Junior secondary & 67 & $23,8 \%$ \\
\hline Senior Secondary & 103 & $36,5 \%$ \\
\hline Diploma & 56 & $19,9 \%$ \\
\hline Graduate & 29 & $10,3 \%$ \\
\hline Post graduate & 9 & $3,2 \%$ \\
\hline Total & 282 & $100,0 \%$ \\
\hline
\end{tabular}

The period during which the business of the respondents is established is documented in Table 4 . The majority of the enterprises in the survey $(40,1 \%)$ were started between 2001 and 2005. Around 37,2\% (105) of the enterprises in the survey had started their business between 1996 and 2000. Only $20,9 \%$ (59) of the respondents started the business prior to 1996 . 
Table 4: Business inception

\begin{tabular}{l|c|c}
\hline Year(s) & Frequency & Per cent \\
\hline Prior to 1996 & 59 & $20,9 \%$ \\
\hline $1996-2000$ & 105 & $37,2 \%$ \\
\hline $2001-2005$ & 113 & $40,1 \%$ \\
\hline 2006 & 2 & $0,7 \%$ \\
\hline Total & 279 & $98,9 \%$ \\
\hline No response & 3 & $1,1 \%$ \\
\hline Total & 282 & $100,0 \%$ \\
\hline
\end{tabular}

Table 5 records the forms of businesses owned by the respondents. The majority of the owner/managers $(58,5 \%)$ in the survey indicated that their chosen form of legal entity was Close Corporation (CC) because of the limited liability aspect and ease of registration aspect. Approximately 14,2\% (40) of the respondents had opted for a sole trader form of business ownership while $18,1 \%$ (51) of respondents opted for the private company form of ownership.

\section{Table 5: Form of business ownership}

\begin{tabular}{l|c|c}
\hline Type of Ownership & Frequency & Per cent \\
\hline Sole trader & 40 & $14,2 \%$ \\
\hline Partnership & 24 & $8,5 \%$ \\
\hline Closed corporation & 165 & $58,5 \%$ \\
\hline Private company & 51 & $18,1 \%$ \\
\hline Other & 1 & $0,4 \%$ \\
\hline Total & 281 & $99,6 \%$ \\
\hline No response & 1 & $0,4 \%$ \\
\hline Total & 282 & $100,0 \%$ \\
\hline
\end{tabular}

Respondents were interviewed to ascertain the level of awareness of certain government initiatives put in place to assist the sector to grow and if they have at any stage in their respective business life cycle made use of the government initiatives that were made available to boost economic growth within the sector.

Table 6 presents the survey results regarding the level of awareness of respondents of the various government support agencies/initiatives. When respondents were asked if they had heard of any of the listed government support initiatives, the majority $(82,1 \%)$ of respondents had indicated that they had heard of the Centre for Small Business Promotions (CSBP).

Approximately 65\% (182) of the respondents had heard of the Industrial Development Corporation (IDC) and 66.8\% (187) of the respondents had heard of Manufacturing Advisory Centre's (now part of Small Enterprise Development Agency). The majority (91.4\%) of respondents indicated that they never heard of Khula Enterprises. Of the respondents interviewed, only 30,7\% (86) of respondents indicated that they heard of Umsobomvu Youth Fund (UYF), a fund set up to focus on the youth of South Africa (below the age of 35).

From observing and talking with entrepreneurs, many were not aware that UYF contributed a substantial amount of funds to service providers to set up business plans for existing and prospective entrepreneurs.

Table 6: Awareness of the government support agencies

\begin{tabular}{|c|c|c|c|c|}
\hline $\begin{array}{l}\text { Government support } \\
\text { agency }\end{array}$ & Measure & Yes & No & Total \\
\hline \multirow{2}{*}{$\begin{array}{l}\text { Center for Small } \\
\text { Business Promotion } \\
\text { (CSBP) }\end{array}$} & Count & 230 & 50 & 280 \\
\hline & $\%$ & $82,1 \%$ & $17,9 \%$ & $100,0 \%$ \\
\hline \multirow{2}{*}{$\begin{array}{l}\text { South African Micro } \\
\text { Finance (Apex) Fund }\end{array}$} & Count & 99 & 180 & 279 \\
\hline & $\%$ & $35,5 \%$ & $64,5 \%$ & $100,0 \%$ \\
\hline \multirow{2}{*}{$\begin{array}{l}\text { Industrial } \\
\text { Development } \\
\text { Corporation (IDC) }\end{array}$} & Count & 182 & 98 & 280 \\
\hline & $\%$ & $65,0 \%$ & $35,0 \%$ & $100,0 \%$ \\
\hline \multirow{2}{*}{$\begin{array}{l}\text { Export Incentives } \\
\text { (Department of Trade } \\
\text { and Industries) }\end{array}$} & Count & 162 & 117 & 279 \\
\hline & $\%$ & $58,1 \%$ & $41,9 \%$ & $100,0 \%$ \\
\hline \multirow{2}{*}{$\begin{array}{l}\text { Manufacturing } \\
\text { Advisory Centers } \\
\text { (Now SEDA) }\end{array}$} & Count & 187 & 93 & 280 \\
\hline & $\%$ & $66,8 \%$ & $33,2 \%$ & $100,0 \%$ \\
\hline \multirow{2}{*}{ Competitiveness Fund } & Count & 37 & 243 & 280 \\
\hline & $\%$ & $13,2 \%$ & $86,8 \%$ & $100,0 \%$ \\
\hline \multirow{2}{*}{ Khula Enterprise } & Count & 24 & 256 & 280 \\
\hline & $\%$ & $8,6 \%$ & $91,4 \%$ & $100,0 \%$ \\
\hline \multirow{2}{*}{ Brain } & Count & 13 & 266 & 279 \\
\hline & $\%$ & $4,7 \%$ & $95,3 \%$ & $100,0 \%$ \\
\hline \multirow{2}{*}{$\begin{array}{l}\text { Umsobomvu Youth } \\
\text { Fund (UYF) }\end{array}$} & Count & 86 & 194 & 280 \\
\hline & $\%$ & $30,7 \%$ & $69,3 \%$ & $100,0 \%$ \\
\hline
\end{tabular}

Following on from the "heard of support agencies" question, respondents were asked to indicate if they had in fact made use of the government support agencies for informational and/or finance requirements.

From Table 7, around 66,3\% (185) of the respondents indicated that they had used the services of CSBP while $56,8 \%$ (158) of the respondents had made use of the services of the IDC for information relating to funding (or tried to make use of for securing loans).

While only $41 \%$ (114) of the respondents had made use of SEDA for informational/financial purposes, almost none of the respondents indicated that they made use of the services of Khula or UYF. 
Table 7: Usage of government support agencies

\begin{tabular}{|c|c|c|c|c|}
\hline $\begin{array}{c}\text { Government support } \\
\text { agency }\end{array}$ & Measure & Yes & No & Total \\
\hline \multirow{2}{*}{ CSBP } & Count & 185 & 94 & 279 \\
\hline & $\%$ & $66,3 \%$ & $33,7 \%$ & $100,0 \%$ \\
\hline \multirow{2}{*}{$\begin{array}{l}\text { South African Micro } \\
\text { Finance (Apex) Fund }\end{array}$} & Count & 62 & 217 & 279 \\
\hline & $\%$ & $22,2 \%$ & $77,8 \%$ & $100,0 \%$ \\
\hline \multirow{2}{*}{$\begin{array}{l}\text { Industrial } \\
\text { Development } \\
\text { Corporation (IDC) }\end{array}$} & Count & 158 & 120 & 278 \\
\hline & $\%$ & $56,8 \%$ & $43,2 \%$ & $100,0 \%$ \\
\hline \multirow{2}{*}{$\begin{array}{l}\text { Export Incentives } \\
\text { Export Incentives } \\
\text { (Department of Trade } \\
\text { and Industries) }\end{array}$} & Count & 137 & 141 & 278 \\
\hline & $\%$ & $49,3 \%$ & $50,7 \%$ & $100,0 \%$ \\
\hline \multirow{2}{*}{$\begin{array}{l}\text { Manufacturing } \\
\text { Advisory Centers } \\
\text { (Now SEDA) }\end{array}$} & Count & 114 & 164 & 278 \\
\hline & $\%$ & $41,0 \%$ & $59,0 \%$ & $100,0 \%$ \\
\hline \multirow{2}{*}{$\begin{array}{l}\text { Competitiveness } \\
\text { Fund }\end{array}$} & Count & 9 & 269 & 278 \\
\hline & $\%$ & $3,2 \%$ & $96,8 \%$ & $100,0 \%$ \\
\hline \multirow{2}{*}{ Khula Enterprises } & Count & 1 & 277 & 278 \\
\hline & $\%$ &, $4 \%$ & $99,6 \%$ & $100,0 \%$ \\
\hline \multirow{2}{*}{ Brain } & Count & 0 & 278 & 278 \\
\hline & $\%$ & $0 \%$ & $100,0 \%$ & $100,0 \%$ \\
\hline \multirow{2}{*}{$\begin{array}{l}\text { Umsobomvu Youth } \\
\text { fund (UYF) }\end{array}$} & Count & 0 & 278 & 278 \\
\hline & $\%$ & $0 \%$ & $100,0 \%$ & $100,0 \%$ \\
\hline
\end{tabular}

Table 8 demonstrates the survey results when the respondents were asked why they have not made use of or (in their opinion) not heard of government initiatives to assist the SMME sector.

From Table 8, 19,5\% (55) of the respondents felt that government initiatives would not be beneficial to them. A larger group of the respondents $(36,9 \%)$ felt that government departments had too much 'red tape' and they were overwhelmed with paper work that ultimately might result in nothing. Nevertheless, only a very small percentage of the respondents $(4,6 \%)$ were of the opinion that government departments (initiatives offered) were incompetent. Many of the respondents $(36,2 \%)$ opted to tick the "other" option on the questionnaire.

During the survey, many respondents indicated that they made use of assistance from specialists other than government. From interviewing and observing respondents, many of them indicated that they made use of the services of business consultants/external specialists such as accountants/tax specialists, product/service specialists, information technology (IT) specialists, attorneys, etc. Service delivery from government departments came across as a more contentious issue.
Table 8: Opinions on government support services

\begin{tabular}{l|c|c}
\hline Opinions on government services & Frequency & Per cent \\
\hline $\begin{array}{l}\text { I am not interested to know about } \\
\text { government services offered } \\
\text { because I feel ultimately it won't } \\
\text { benefit me as a business person }\end{array}$ & 55 & $19,5 \%$ \\
\hline Too much red tape (beauracracy) & 104 & $36,9 \%$ \\
\hline Government institutions are & 13 & $4,6 \%$ \\
\hline Other & 102 & $36,2 \%$ \\
\hline Total & 274 & $97,2 \%$ \\
\hline No response & 8 & $2,8 \%$ \\
\hline Total & 282 & $100,0 \%$ \\
\hline
\end{tabular}

Table 9 documents the ratings of the respondents on the services provided by the government incentives. From Table 9, the majority of the respondents opted for the option "neither poor nor well" (fence sitters).

Approximately $79,9 \%$ (223) of the respondents rated the overall government promotion of the small business sector as neither poor nor well. The impact of small enterprise support structures was given a $64,9 \%$ (181) response in the category neither poor nor well while $39,2 \%$ (109) of the respondents rated the impact of BEE procurement initiatives as 'well'.

Approximately 35,5\% (99) of the respondents rated labor legislation polices in the category 'well', while 4,3\% (12) of the respondents considered labor legislation as 'very well'.

From Table 10, the respondents were asked to consider the biggest obstacles they perceived to be frustrating them in achieving their respective business goals. Approximately $91,6 \%$ (259) of the respondents said that tough competition was hampering them in achieving their respective goals.

On the other hand, $65.4 \%$ (185) said that corruption negatively affected their businesses in some way or another. Of those interviewed, $46.4 \%$ (131) of the respondents said that government 'red tape' were not an impeding factor on their businesses, while $53.6 \%$ (151) said that it was negatively affecting their respective businesses. Labour and tax issues were particularly alluded to in the interviews. 
Table 9: Rating of government initiatives

\begin{tabular}{|c|c|c|c|c|c|c|c|}
\hline Services & Measure & $\begin{array}{l}\text { Very } \\
\text { poor }\end{array}$ & Poor & Average & Well & $\begin{array}{l}\text { Very } \\
\text { well }\end{array}$ & Total \\
\hline \multirow{2}{*}{$\begin{array}{l}\text { Overall } \\
\text { promotion of } \\
\text { small } \\
\text { enterprise }\end{array}$} & Count & 0 & 32 & 223 & 17 & 7 & 279 \\
\hline & $\%$ & $0,0 \%$ & $11,5 \%$ & $79,9 \%$ & $6,1 \%$ & $2,5 \%$ & $100,0 \%$ \\
\hline \multirow{2}{*}{$\begin{array}{l}\text { Communicatio } \\
\text { n of small } \\
\text { enterprise } \\
\text { incentives }\end{array}$} & Count & 1 & 36 & 220 & 14 & 7 & 278 \\
\hline & $\%$ & $0,4 \%$ & $12,9 \%$ & $79,1 \%$ & $5,0 \%$ & $2,5 \%$ & $100,0 \%$ \\
\hline \multirow{2}{*}{$\begin{array}{l}\text { Communicatio } \\
\mathrm{n} \text { of legislation }\end{array}$} & Count & 4 & 47 & 206 & 14 & 8 & 279 \\
\hline & $\%$ & $1,4 \%$ & $16,8 \%$ & $73,8 \%$ & $5,0 \%$ & $2,9 \%$ & $100,0 \%$ \\
\hline \multirow{2}{*}{$\begin{array}{l}\text { Impact of } \\
\text { government } \\
\text { incentives in } \\
\text { general }\end{array}$} & Count & 0 & 32 & 212 & 30 & 5 & 279 \\
\hline & $\%$ & $0,0 \%$ & $11,5 \%$ & $76,0 \%$ & $10,8 \%$ & $1,8 \%$ & $100,0 \%$ \\
\hline \multirow{2}{*}{$\begin{array}{l}\text { Impact of } \\
\text { small } \\
\text { enterprise } \\
\text { support } \\
\text { structures }\end{array}$} & Count & 0 & 23 & 181 & 72 & 3 & 279 \\
\hline & $\%$ & $0,0 \%$ & $8,2 \%$ & $64,9 \%$ & $25,8 \%$ & $1,1 \%$ & $100,0 \%$ \\
\hline \multirow{2}{*}{$\begin{array}{l}\text { Impact of } \\
\text { export } \\
\text { incentives }\end{array}$} & Count & 1 & 38 & 132 & 106 & 1 & 278 \\
\hline & $\%$ & $0,4 \%$ & $13,7 \%$ & $47,5 \%$ & $38,1 \%$ &, $4 \%$ & $100,0 \%$ \\
\hline \multirow{2}{*}{$\begin{array}{l}\text { Impact of BEE } \\
\text { procurement }\end{array}$} & Count & 0 & 40 & 121 & 109 & 8 & 278 \\
\hline & $\%$ & $0,0 \%$ & $14,4 \%$ & $43,5 \%$ & $39,2 \%$ & $2,9 \%$ & $100,0 \%$ \\
\hline \multirow{2}{*}{$\begin{array}{l}\text { Impact of } \\
\text { labour } \\
\text { legislation }\end{array}$} & Count & 3 & 43 & 122 & 99 & 12 & 279 \\
\hline & $\%$ & $1,1 \%$ & $15,4 \%$ & $43,7 \%$ & $35,5 \%$ & $4,3 \%$ & $100,0 \%$ \\
\hline \multirow{2}{*}{$\begin{array}{l}\text { Impact of } \\
\text { import/export } \\
\text { legislation }\end{array}$} & Count & 0 & 39 & 102 & 54 & 84 & 279 \\
\hline & $\%$ & $0,0 \%$ & $14,0 \%$ & $36,6 \%$ & $19,4 \%$ & $30,1 \%$ & $100,0 \%$ \\
\hline \multirow{2}{*}{$\begin{array}{l}\text { Impact of skills } \\
\text { development } \\
\text { programs }\end{array}$} & Count & 3 & 47 & 163 & 55 & 10 & 278 \\
\hline & $\%$ & $1,1 \%$ & $16,9 \%$ & $58,6 \%$ & $19,8 \%$ & $3,6 \%$ & $100,0 \%$ \\
\hline
\end{tabular}

Approximately 51\% (143) considered low growth in their respective sector to be a contributing factor to them not achieving all their business goals. Approximately 62,5\% (176) of the respondents said that the lack of government support was not an impediment to achieving their respective goals.

Of the respondents interviewed, 73,4\% (207) considered BEE not to be an impediment to them achieving their business goals, whilst $83,8 \%$ (235) regarded access to finance to be a constraint to achieving their business goals. Approximately $16,2 \%$ (47) of the respondents reveal that access to finance was not a constraining factor, whilst $91,6 \%$ of the respondents considered tough competition as a bigger obstacle to growth than access to finance.

Table 11a displays a cross tabulation of the impact of the overall promotion of SMMEs in relation to the labor force expansion in the past two years.
Table 10: Obstacles to achieving your business goals

\begin{tabular}{l|l|l|l|l}
\hline Obstacle & Measure & Yes & No & Total \\
\hline \multirow{2}{*}{ Tough competition } & Count & 259 & 23 & 282 \\
\cline { 2 - 5 } & $\%$ & $91.6 \%$ & $8.4 \%$ & $100.0 \%$ \\
\hline \multirow{2}{*}{\begin{tabular}{l} 
Corruption \\
\cline { 2 - 4 } $\begin{array}{l}\text { Government Red- } \\
\text { tape }\end{array}$
\end{tabular}} & Count & 185 & 97 & 282 \\
\cline { 2 - 5 } & $\%$ & $65.4 \%$ & $34.6 \%$ & $100.0 \%$ \\
\hline $\begin{array}{l}\text { Low/no growth in } \\
\text { your respective } \\
\text { sector }\end{array}$ & Count & 151 & 131 & 282 \\
\cline { 2 - 5 } & $\%$ & $53.6 \%$ & $46.4 \%$ & $100.0 \%$ \\
\hline \multirow{2}{*}{$\begin{array}{l}\text { Lack of government } \\
\text { support }\end{array}$} & Count & 106 & 173 & 282 \\
\cline { 2 - 5 } & $\%$ & $37.5 \%$ & $62.5 \%$ & $100.0 \%$ \\
\hline $\begin{array}{l}\text { Black economic } \\
\text { empowerment } \\
\text { (BEE) }\end{array}$ & Count & 75 & 207 & 282 \\
\cline { 2 - 5 } $\begin{array}{l}\text { Lack of access to } \\
\text { finance }\end{array}$ & Count & 235 & 47 & 282 \\
\cline { 2 - 5 } & $\%$ & $83.8 \%$ & $16.2 \%$ & $100.0 \%$ \\
\hline
\end{tabular}

The Chi-square test results are presented in Table 11b. The null hypothesis stated that there is no relationship between government support initiatives and SMME growth in terms of job creation. The Chi-square results are insignificant $(\mathrm{p}>$ $0.05)$, indicating an insignificant relation between government incentives and the increased labor force over the last two years.

Table 12a represents a cross tabulation of the impact of the overall promotion of SMMEs in relation to the year-on-year revenue increases since business inception. The Chi-square test results demonstrated in Table $12 \mathrm{~b}$ are insignificant $(\mathrm{p}>$ 0.05 ), which indicates that the overall promotion of small enterprises did not have a positive effect on improving yearon-year turnover for SMMEs. 
Table 11a: Promotion of SMMEs and job creation

\begin{tabular}{|c|c|c|c|c|c|c|}
\hline \multirow{2}{*}{$\begin{array}{l}\text { (Y) } \\
\text { Overall } \\
\text { promotion } \\
\text { of } \\
\text { SMMEs* } \\
\text { (X) Labor } \\
\text { force } \\
\text { expansion }\end{array}$} & \multirow[b]{2}{*}{ Degree } & \multirow[b]{2}{*}{ Measure } & \multicolumn{4}{|c|}{$\begin{array}{l}\text { (X) In the past two years has your labor } \\
\text { force: }\end{array}$} \\
\hline & & & Expanded & Contracted & $\begin{array}{l}\text { Not } \\
\text { changed }\end{array}$ & Total \\
\hline \multirow{12}{*}{$\begin{array}{l}\text { (Y) } \\
\text { Overall } \\
\text { promotion } \\
\text { of } \\
\text { SMMEs }\end{array}$} & \multirow{4}{*}{$\begin{array}{l}\text { Very } \\
\text { poor/ } \\
\text { Poor }\end{array}$} & Count & 10 & 7 & 14 & 31 \\
\hline & & $\begin{array}{l}\% \\
\text { within } \\
\text { (Y) }\end{array}$ & $32,3 \%$ & $22,6 \%$ & $45,2 \%$ & $100,0 \%$ \\
\hline & & $\begin{array}{l}\% \\
\text { within } \\
\text { (X) }\end{array}$ & $7,6 \%$ & $10,8 \%$ & $17,3 \%$ & $11,2 \%$ \\
\hline & & $\begin{array}{l}\% \text { of } \\
\text { Total }\end{array}$ & $3,6 \%$ & $2,5 \%$ & $5,1 \%$ & $11,2 \%$ \\
\hline & \multirow{4}{*}{$\begin{array}{l}\text { Neither } \\
\text { poor } \\
\text { nor } \\
\text { well }\end{array}$} & Count & 112 & 51 & 59 & 222 \\
\hline & & $\begin{array}{l}\% \\
\text { within } \\
\text { (Y) }\end{array}$ & $50,5 \%$ & $23,0 \%$ & $26,6 \%$ & $100,0 \%$ \\
\hline & & $\begin{array}{l}\% \\
\text { within } \\
(\mathrm{X})\end{array}$ & $85,5 \%$ & $78,5 \%$ & $72,8 \%$ & $80,1 \%$ \\
\hline & & $\begin{array}{l}\% \text { of } \\
\text { Total }\end{array}$ & $40,4 \%$ & $18,4 \%$ & $21,3 \%$ & $80,1 \%$ \\
\hline & \multirow{4}{*}{$\begin{array}{l}\text { Well/ } \\
\text { Very } \\
\text { Well }\end{array}$} & Count & 9 & 7 & 8 & 24 \\
\hline & & $\begin{array}{l}\text { \% } \\
\text { within } \\
\text { (Y) }\end{array}$ & $37,5 \%$ & $29,2 \%$ & $33,3 \%$ & $100,0 \%$ \\
\hline & & $\begin{array}{l}\% \\
\text { within } \\
\text { (X) }\end{array}$ & $6,9 \%$ & $10,8 \%$ & $9,9 \%$ & $8,7 \%$ \\
\hline & & $\begin{array}{l}\% \text { of } \\
\text { Total }\end{array}$ & $3,2 \%$ & $2,5 \%$ & $2,9 \%$ & $8,7 \%$ \\
\hline \multirow{4}{*}{ Total } & & Count & 131 & 65 & 81 & 277 \\
\hline & & $\begin{array}{l}\% \\
\text { within } \\
\text { (Y) }\end{array}$ & $47.3 \%$ & $23,5 \%$ & $29,2 \%$ & $100,0 \%$ \\
\hline & & $\begin{array}{l}\% \\
\text { within } \\
\text { (X) }\end{array}$ & $100.0 \%$ & $100,0 \%$ & $100,0 \%$ & $100,0 \%$ \\
\hline & & $\begin{array}{l}\% \text { of } \\
\text { Total }\end{array}$ & $47.3 \%$ & $23,5 \%$ & $29,2 \%$ & $100,0 \%$ \\
\hline
\end{tabular}

Table 11b: Chi-square test

\begin{tabular}{l|c|l|c}
\hline Coefficient & \multicolumn{1}{|l|}{ Value } & Df & Asymp. Sig. (2-sided) \\
\hline Pearson Chi-Square & 6,165 & 4 & 0,187 \\
\hline Likelihood Ratio & 5,982 & 4 & 0,201 \\
\hline $\begin{array}{l}\text { Linear-by-Linear } \\
\text { Association }\end{array}$ & 0,973 & 1 & 0,324 \\
\hline N of Valid Cases & 277 & & \\
\hline
\end{tabular}

Table 12a: Promotion of SMMEs and turnover increases

\begin{tabular}{|c|c|c|c|c|c|}
\hline \multirow{2}{*}{$\begin{array}{c}\text { (Y) Overall } \\
\text { promotion } \\
\text { of SMMEs * } \\
(\mathrm{X}) \\
\text { Turnover } \\
\text { increases }\end{array}$} & \multirow[b]{2}{*}{ Degree } & \multirow[b]{2}{*}{ Measure } & \multicolumn{3}{|c|}{$\begin{array}{c}\text { (X) Year-on-year turnover } \\
\text { increases since business inception }\end{array}$} \\
\hline & & & Yes & No & Total \\
\hline \multirow{12}{*}{$\begin{array}{l}\text { (Y) Overall } \\
\text { promotion } \\
\text { of SMMEs }\end{array}$} & \multirow{4}{*}{$\begin{array}{l}\text { Very } \\
\text { poor/ } \\
\text { Poor }\end{array}$} & Count & 22 & 10 & 32 \\
\hline & & $\begin{array}{l}\text { \% within } \\
(Y)\end{array}$ & $68,8 \%$ & $31,3 \%$ & $100,0 \%$ \\
\hline & & $\begin{array}{l}\text { \% within } \\
(\mathrm{X})\end{array}$ & $11,1 \%$ & $12,8 \%$ & $11,6 \%$ \\
\hline & & $\%$ of Total & $8,0 \%$ & $3,6 \%$ & $11,6 \%$ \\
\hline & \multirow{4}{*}{$\begin{array}{l}\text { Neither } \\
\text { poor nor } \\
\text { well }\end{array}$} & Count & 158 & 62 & 220 \\
\hline & & $\begin{array}{l}\text { \% within } \\
\text { (Y) }\end{array}$ & $71,8 \%$ & $28,2 \%$ & $100,0 \%$ \\
\hline & & $\begin{array}{l}\text { \% within } \\
\text { (X) }\end{array}$ & $79,8 \%$ & $79,5 \%$ & $79,7 \%$ \\
\hline & & $\%$ of Total & $57,2 \%$ & $22,5 \%$ & $79,7 \%$ \\
\hline & \multirow{4}{*}{$\begin{array}{l}\text { Well/ } \\
\text { Very } \\
\text { well }\end{array}$} & Count & 18 & 6 & 24 \\
\hline & & $\begin{array}{l}\text { \% within } \\
\text { (Y) }\end{array}$ & $75,0 \%$ & $25,0 \%$ & $100,0 \%$ \\
\hline & & $\begin{array}{l}\text { \% within } \\
\text { (X) }\end{array}$ & $9,1 \%$ & $7,7 \%$ & $8,7 \%$ \\
\hline & & $\%$ of Total & $6,5 \%$ & $2,2 \%$ & $8,7 \%$ \\
\hline \multirow{4}{*}{\multicolumn{2}{|c|}{ Total }} & Count & 198 & 78 & 276 \\
\hline & & $\begin{array}{l}\text { \% within } \\
(\mathrm{Y})\end{array}$ & $71,7 \%$ & $28,3 \%$ & $100,0 \%$ \\
\hline & & $\begin{array}{l}\text { \% within } \\
(\mathrm{X})\end{array}$ & $100,0 \%$ & $100,0 \%$ & $100,0 \%$ \\
\hline & & $\%$ of Total & $71,7 \%$ & $28,3 \%$ & $100,0 \%$ \\
\hline
\end{tabular}

Table 12b: Chi-square test

\begin{tabular}{l|l|l|l}
\hline Coefficient & Value & df & $\begin{array}{c}\text { Asymp. } \\
\text { Sig. (2- } \\
\text { sided) }\end{array}$ \\
\hline Pearson Chi-Square & 0,268 & 2 & 0,875 \\
\hline Likelihood Ratio & 0,268 & 2 & 0,875 \\
\hline Linear-by-Linear Association & 0,267 & 1 & 0,606 \\
\hline N of Valid Cases & 276 & & \\
\hline
\end{tabular}

\section{Conclusion}

Promoting the SMME sector so as to create an enabling environment by reducing unemployment and creating a more equitable distribution of wealth is the overall ambition of government support initiatives in South Africa. These initiatives had to ultimately lead to sustainable job creation and increased turnover for the SMME sector. However, 18 years into democracy and from the feedback of this survey, in line with prior studies of similar nature, the indication is that government support initiatives in this regard had been ineffective. Based on the survey conducted in 2007, the results of the Chi-square tests ruled out the significance of the relationship between the government support initiatives and the growth in the SMME sector in the KwaZulu-Natal province, a province with the largest disproportional 
developmental challenges amongst other provinces in South Africa.

The feedback of the survey indicates that the majority of the respondents have not heard of Khula Enterprise and Umsobomvu Youth Fund (UYF), the two primary initiatives that provide finance to start-ups and youth entrepreneurs. Ironically, the primary obstacle to achieving business goals identified by the respondents is lack of access to finance. Despite the lack of awareness of the respective government support initiatives in the SMME sector, the general feeling that there is too much red tape associated with the application and usage of government support initiatives is the primary reason for lack of usage of these initiatives.

Finally, it could be argued that it is the task of government departments to communicate to the industry the initiatives available to them from each of the respective departments, as a significant correlation exists between the awareness and usage of the government support initiatives. The majority of the respondents felt that the services provided by the government support initiatives are neither well nor poor, indicating rooms for improvement in various service areas. The services overally did not as yet have the desired effect. This study contends that the quality of the entrepreneurs as identified above is a critical factor in SMME success and as such, If the government's strategy to use the SMME sector so as to create an enabling environment and correct inbalances created in the main by past restrictive policies is to have any significant success, focus must be placed on developing competent entrepreneurs, especially amongst those classified as previously disadvantaged persons. More focus should be placed on education and the training of budding entrepreneurs in particular in small towns and rural areas.

\section{References}

Advani, A. 1997. Industrial clusters: A support system for small and medium sized enterprise.Washington D.C: Private Sector Development Department, World Bank.

Amsden, A.H. 1997. 'Editorial: Bringing production back in--Understanding Government's economic role in late industrialization', World Development, 25(4):469-480.

Bambara, A. 1995. 'View from the private sector'. In English, P. \& Henault, G. (eds.). Agents of Change - studies on the policy environment for small enterprise in Africa. Ottawa: IDRC, pp. 8-11.

Becattini, G. 1990. The Marshallian industrial district as a socio-economic notion. In E. Goodman \& J. Bamford, eds. Small Firms and Industrial Districts in Italy. London: Routledge.

Birch, D. 1987. Job creation in America: How our smallest companies put the most people to work, New York \& London: Free Press Collier Macmillan.
Birch, D. L. 1979.'The Job Generation Process': Final Report to Economic Development Administration: Cambridge.

Brautigam, D. 1997. 'Substituting for the state: Institutions and industrial development in Eastern Nigeria', World Development, 25(7):1063-1080.

Cortes, M., Berry, A. \& Ishaq, A. 1987. Success in small and medium-scale enterprises: The evidence from Colombia. New York: Published for the World Bank by Oxford University Press.

Colbert, D.T. 1999. 'South African small business growth through interfirm linkages'. Doctoral Thesis. Grahamstown: Rhodes University.

Department of Provincial Affairs. 1998. White Paper on Local Government. Pretoria: Government printer.

Department Trade and Industry. 1995. White Paper on National Strategy for the Development and Promotion of Small Business in South Africa. Pretoria: Government printer.

Dia, M. 1996. Africa's management in the 1990s and beyond: Reconciling indigenous and transplanted institutions, Washington, D.C: World Bank.

Ebersohn, W. 1997. Government reports on small business. Pretoria: Department of Trade and Industry.

Fan, Q. 2009. Innovation for development and the role of government: A perspective from the East Asia and Pacific region. Washington, DC: World Bank Publications.

Ferrand, D. 1997. 'Discontinuity in development--The case of Kenya's "Missing Middle".' Unpublished paper presented at the African Business Systems Conference: Institutionalising Industrialisation in the Era of Economic Reform, Mombasa.

Guzmán, J. \& Santos, F.J. 2001. 'The booster function and the entrepreneurial quality: An application to the province of Seville', Entrepreneurship \& Regional Development, 13(3):211-228.

Harrison, B. 1994. Lean and mean: the changing landscape of corporate power in the age of flexibility. New York: Basic Books.

Hirst, P. \& Zeitlin, J. 1992. 'Flexible specialization versus post-Fordism'. In Storper, M. \& Scott, A. J. (eds.). Pathways to industrialisation and regional development. London: Routledge, pp. 70-115.

Humphrey, J. \& Schmitz, H. 1995. Principles for promoting clusters \& networks of SMEs. Viena: Unido.

Kaplinsky, R. 2010. 'Restructuring firms to cope in a global economy'. IDS Policy Briefing, March. Institute of Development Studies (IDS), University of Sussex. 
Khoza, R. 1994. The need for an Afro-centric approach to management. Johannesburg: Centre for Business Studies, Graduate School of Business Administration, University of the Witwatersrand.

Koshiro, K. 1990. 'Japan'. In Sengenberger, W. Loveman, G. \& Piore, M. J. (eds.). The reemergence of small enterprises: Industrial restructuring in industrialised countries. Geneva: International Institute of Labour Studies, pp. 173-222.

Kuroda, A. \& Kasajima, S. 1987. The development strategies for the small and medium scale industries in Thailand. Ministry of Thailand: Small/Medium Industry Promotion and Finance Project, Department of Industrial Promotion.

McCormick, D. 1999. 'African enterprise clusters and industrialization: Theory and reality', World Development, 27(9):1531-1551.

McCormick, D., Kinyanjui, M.N. \& Ongile, G. 1997. 'Growth and barriers to growth among Nairobi's small and medium-sized garment producers', World Development, 25(7):1095-1110.

McPherson, M.A. 1996. 'Growth of micro and small enterprises in southern Africa', Journal of Development Economics, 48(2):253-277.

Mead, D. 1999. 'MSEs tackle both poverty and growth (but in different proportions)'. In King, K. \& McGrath, S. (eds.). Enterprises in Africa - Between poverty and growth. London: IT Publications, pp. 61-70.

Meyanathan, S.D. 1994. Industrial structures and the development of small and medium enterprise linkages: Examples from East Asia. Washington, DC,: World Bank Publications.

Naicker, N.I. 2006. 'Factors contributing to women being successful in the SMME sector'. A mini dissertation submitted in partial fulfilment of the requirements for the degree Masters in Business Administration in the Faculty of Management at the University of Johannesburg.

Organisation for Economic Co-operation and Development (OECD). 1985. 'Employment in small and large firms: Where have the jobs come from?', Employment Outlook. Paris: OECD.

Papoutsis, C. 1996. 'Promoting the development of fastgrowing companies', Monthly Newsletter, Brussels, European Commission (June).

Pedersen, P.O. \& McCormick, D. 1996. Small enterprises: Flexibility and networking in an African context. London: Longhorn.
Peters, R.M. 2009. 'SMME development initiatives and its constraints to growth in South Africa'. Doctoral Thesis. Johannesburg: University of Johannesburg.

Pretorius, M. \& Van Vuuren, J.J. 2003. 'Contribution of support and incentive programs to entrepreneurial orientation and start-up culture in South Africa', South African Journal of Economic and Management Sciences, 6(3):514-528.

Qualman, R. 1988. 'Why do(n't) they innovate? Explaining diverse SME adjustment strategies in Africa'. Paper presented at the Seminar of the EADI Working Group on Industrialisation 18/19 Sept., The Hague.

Republic of South Africa. 1996. Growth, employment and reconstruction strategy. Pretoria: Government printer.

Reynolds, P.D. et al. 2003. Global Entrepreneurship Monitor (GEM): Executive report. Springer, Small Business Economics, 24:205-231.

Rogerson, C.M. 2000. 'Successful SMEs in South Africa: The case of clothing producers in the Witwatersrand', Development Southern Africa, 17(5):687-716.

Rogerson, C.M \& Rogerson, J. 1995. 'The decline of manufacturing in inner-city Johannesburg 1980--1994', Urban Forum, 6:1. pp. 17-42.

Sengenberger, W., Loveman, G. \& Piore, M. 1990. The reemergence of small enterprises: Industrial restructuring in industrialised countries. Geneva: International Institute for Labour Studies.

Späth, B. 1994. Implications of developed districts for upgrading small firms in developing countries: A synthesis of discussion. InUNCTAD-ITD. Technological dynamism in developed districts: An alternative approach to industrialisation in developing countries. Geneva: UNCTAD, pp. 287-343.

Tendler, J. \& Amorim, M.A. 1996. Small firms and their helpers: lessons on demand. World Development, 24(3), pp.407-426.

Timmons, J. 1994. New venture creation: entrepreneurship for the 21st century, Boston: McGraw-Hill/Irwin.

Yankson. P. W. 1996. 'Small-scale aluminium industry in Ghana'. In Pedersen, P.O. \& McCormick, D. (eds.). Small enterprises: Flexibility and networking in an African context. Kenya,Longham, pp. 63-78. 